\title{
Likelihood of adrenaline auto-injectors being mis-prescribed by primary care physicians
}

\author{
DA Fischer
}

From Canadian Society of Allergy and Clinical Immunology Annual Scientific Meeting 2009

Halifax, Canada. 22-25 October 2009

\section{Background}

Primary care physicians and emergency dept. physicians are often called upon by patients to determine whether individual patients should be prescribed adrenaline auto-injectors (AAI's). Although these patients are often also referred to an allergist to help determine whether their condition warrants this, the wait may often be for months. We set out to determine how accurate referring physicians are in determining that patients should be prescribed AAI's.

\section{Method}

We prospectively collected data on all patients referred to our practice for anaphylaxis assessment in the Year 2007. These patients were assessed and asked if an AAI script had been written. Patients were included whether or not they actually filled the prescription.

\section{Results}

226 patients were included. 46 of the prescription were deemed unnecessary (20.4\%). The most commonly noted diagnoses that resulted in an AAI being prescribed unnecessarily were: idiopathic urticaria without other anaphylactic signs (17 patients) and large local reactions (LLR) to insect venom (11 patients). Other diagnoses included ACD to latex, oral allergy syndrome and vocal cord dysfunction. The remainder of the patients (180) had had enough signs and symptoms of anaphylaxis to warrant an AAI prescription.

\section{Conclusion}

Eighty per cent of the time, primary care physicians were correct in their clinical suspicion that their patient should be given an AAI prescription. If one excludes the LLR patients, which could be accomplished through

University of Western Ontario. Barrie, Ontario, Canada
CPD, the accuracy would increase to $84 \%(35 / 215)$. The vast majority of patients being prescribed AAI's by primary physicians are receiving them appropriately.

Published: 12 May 2010

doi:10.1186/1710-1492-6-S1-P4

Cite this article as: Fischer: Likelihood of adrenaline auto-injectors being mis-prescribed by primary care physicians. Allergy, Asthma \& Clinical Immunology 2010 6(Suppl 1):P4.
Submit your next manuscript to BioMed Central and take full advantage of:

- Convenient online submission

- Thorough peer review

- No space constraints or color figure charges

- Immediate publication on acceptance

- Inclusion in PubMed, CAS, Scopus and Google Scholar

- Research which is freely available for redistribution

Submit your manuscript at www.biomedcentral.com/submit
C Biomed Central 